\title{
The Duopoly Policy in the Brazilian Model of Telecommunications Reform*
}

\author{
César Mattos $^{* *}$ \\ Paulo Coutinho ${ }^{* * *}$
}

Summary: 1. Introduction; 2. The duopoly policy in the BMTR; 3. Revisiting the main theoretical arguments in favor of limiting entry; 4. A theoretical model for understanding the trade-offs among competition, scale economies and privatization revenues; 5. Lessons from the international experience and conclusions.

Keywords: privatization; telecommunications; duopoly policy.

JEL codes: L33; L43; L96.

One of the important characteristics of the Brazilian Model of Telecommunications Reform (BMTR) was the adoption of a duopoly policy, constraining the entry of new players in the wire segment in the transitional phase until free competition in 2002. This policy was also used in the reform experience of the United Kingdom in telecommunications in the $80^{\prime} \mathrm{s}$. The theoretical explanations behind this kind of policy are not strong enough to justify the duopoly policy in telecommunications. The most plausible idea rests on the prominent role conferred to privatization revenues in the design of the reform as a means of helping the efforts to consolidate price stabilization in the country. We introduce a model with the trade-offs between competition, duplication of fixed costs and privatization revenues. Despite the importance of fixed costs in the objective function of the regulator, we show that the privatization revenue target is the aspect, which justifies the imposition of entry constraints. The British experience shows that the sacrifice of this kind of policy regarding efficiency in the long run can be substantial.

${ }^{*}$ This paper was received in Aug. 2001 and approved in Mai. 2003. The authors thanks the comments by Donald Hay, Rodrigo Penaloza and two anonymous referees on the preliminary versions of this article.

** Doutor em Economia, Consultor da Câmara dos Deputados e Professor Substituto da $\mathrm{UNB} / \mathrm{DF}$.

${ }^{* * *} \mathrm{PhD}$ em Economia pela University of Pennsylvania e Professor Titular do Departamento de Economia da UNB/DF e do CERME/UNB. 
Uma das características mais importantes do Modelo Brasileiro de Reforma das Telecomunicações foi a adoção de uma política de duopólio, restringindo a entrada de novas empresas no segmento de telefonia fixa durante a fase de transição até a livre concorrência a ser adotada a partir de 2002. Essa política foi também utilizada na experiência de reforma das telecomunicações ocorrida no Reino Unido na década de 80. As explicações teóricas para justificar a adoção deste tipo de política não são satisfatórias o suficiente para justificar a política de duopólio como prescrição de política nas telecomunicações. A idéia mais plausível se baseia no papel proeminente conferido às receitas de privatização no desenho da reforma como forma de auxiliar os esforços de consolidação da estabilização de preços no País. Introduzimos um modelo que apresenta os trade-offs entre concorrência, duplicação de custos fixos e receitas de privatização. A despeito da importância dos custos fixos na função objetivo do regulador, mostramos que a meta de aumentar as receitas esperadas de privatização é o aspecto que acaba por justificar a imposição das restrições de entrada. A experiência britânica mostra que o sacrifício deste tipo de política no que tange à eficiência no longo prazo pode ser substantiva.

\section{Introduction}

In this article, our goal is to address the substantive motivations for introducing entry constraints and their impact on efficiency in the Brazilian Model of Telecommunications Reform (BMTR).

The first motivation for entry constraints in telecom is the allocation of the spectrum, a scarce resource, regarding wireless segments. However, we shall abstain from discussing spectrum allocation. ${ }^{1}$ Our interest is concentrated on the rationale for a temporary duopoly policy designed to the BMTR in the wire segment, presented in the next section, which resembles the policy adopted after privatization in 1984 in the UK.

There are at least four theoretical arguments in favor of limiting entry as discussed in section 3. They are the non-sustainability of a natural monopoly, the imposition of universal service constraints requiring cross-subsidy between lines of business, the business stealing effect when there are scale economy as in the classical paper of Mankiw and Whinston and the possibility of under-investment of the operators when there is competition. But we are of the opinion that the main motivation for the behavior of the regulator in imposing entry constraints in

\footnotetext{
${ }^{1}$ A survey on the issue of spectrum allocation can be found in Cramton (2002).
} 
the BMTR relates to the trade-off between the introduction of competition, scale economies and privatization revenues. That was the case of Brazil.

On one hand, more entry increases the overall fixed costs of the sector, this reducing the total social surplus. Moreover, the expectation of more entry makes the state-owned companies about to be privatized less profitable. This makes the "object" of the privatization auction less valuable for bidders that respond by bidding less aggressively. This reduces the winner bid equilibrium of the privatization auction, dropping privatization revenues. Given that most regulators around the world, including Brazil, have a special concern over the "fiscal role" of the privatization, this by-product is not welcome. On the other hand, more entry increases competition that reduces market power, increasing the total social surplus net of fixed costs.

Even considering competition in telecommunications as the core of the reform, Brazilian regulators have been concerned about privatization revenues that would contribute to the ongoing stabilization plan and as a measure of the success of the program. Indeed, Law 8031 of 1990 that launched privatization policy in Brazil quoted explicitly "privatization revenues" as one of the main goals of the program.

Another relevant set of theoretical considerations that might be considered has a more dynamic nature. It is commonly accepted that the lack of external threat towards the inside market players weakens the competition between them. The incentive for collusive behavior increases with a smaller number of players, not only because of the greater difficulty of the enforcement of an agreement, but as shown by Selten (1973), presented by Phlips (1995:2), as a Nash perfect sub-game equilibrium of the market game. In this author's interesting particular example, the existence of four players results in a cooperative cartel equilibrium (that does not require communication), while more than five players results in at least one maverick firm free-riding on the cartel and benefiting consumers.

A very important dynamic relationship is the one between competition and innovation. Since Schumpeter, there has been a lot of work on this issue. On one hand, that author has stressed that this could be a negative relationship, since competition would dissipate the rents from innovations, reducing the incentive to search for technological improvements. On the other hand, more rivals may stimulate more efforts from the market players to be the first to obtain a new product and/or process. The net effect of more competition on the incentive to innovate is ambiguous, though, as shown by Viscusi et al. (1995:89-93). ${ }^{2}$ Economists today

\footnotetext{
${ }^{2}$ The statement that the authors reproduce (p. 92) from Scherer and Ross (1982) is informative about their position on this trade-off: "what is needed for rapid technical progress is a subtle blend of competition and monopoly, with more emphasis in general on the former than the latter,
} 
tend to think that this relationship is even more complicated, being market concentration, the degree of competition ${ }^{3}$ and the incentive to innovate, endogenous variables affecting one another in different ways, depending on the specific sectors within which they are inserted. ${ }^{4}$

In sections 3 and 4, we leave dynamics aside and focus on static considerations, though we quote some dynamic arguments as raised by British economists assessing the UK experience with the duopoly policy in telecommunications. In section 4, we formalize the main issue of this paper, that is, the imposition of entry constraints in the BMTR. We focus on the short-run static trade-off between privatization revenues that increases when the number of competitors shrinks and the total social surplus (including fixed costs) that holds an ambiguous relationship with the number of competitors. On one hand, more competitors reduce prices, increasing net welfare. On the other hand, more competitors increase wasteful fixed costs, dropping welfare. An important finding is that, since market forces naturally constrain the number of players, the exogenous entry constraint may be redundant, even if one considers the target of privatization revenues. Only when this goal is strong enough relative to the total social surplus in the regulator's objective function, it will make sense to impose an exogenous entry constraint. That seems to be the case.

Section 5 summarizes the duopoly policy in the UK, as described by Vickers and Yarrow (1988) and Armstrong et al. (1994), and concludes.

\section{The Duopoly Policy in the BMTR}

After restructuring and privatising the Brazilian state-owned holding, TELEBRAS, the Brazilian government started on another important step in the reform towards a more liberalised telecommunications sector, auctioning new grants to entrants.

The system designed was closely related to the temporary duopoly model of the UK. ${ }^{5}$ Each privatized wire company, local and long distance (EMBRATEL) would face only one competitor with a grant to explore the same telephone service in the same geographic area until December 2001, when controls of entry were lifted. All

and the role of monopolistic elements diminishing when rich technological opportunities exist".

${ }^{3}$ Note that less concentration and competition do not always go in the same direction in these models.

${ }^{4}$ Reinganum (1989) provides a survey of models describing the web of possible interactions. Nelson and Winter (1982) stress on the "Darwinian" role of competition. Sutton (1998) advances a rich new framework of this relationship based on the "bounds approach".

${ }^{5}$ See Armstrong et al. (1994:7), Armstrong (1998) and Cave and Williansom (1996). 
new grants were also conceded after a public auction. ${ }^{6}$ The new companies that emerged from this process in the BMTR were called "mirror companies".

The entrants in the wire segment could operate exactly in the same areas as the incumbent privatized regional companies and had the same cross-ownership constraints in the short-run. For instance, the mirror company in region I could operate all local services in that region and all intra-area long distance services in that same region, but not inter-area services, just like with the constraints imposed on the privatized regional company. The same constraints hold for the other two regional mirror companies. ${ }^{7}$

In the case of the mirror company of the long distance carrier EMBRATEL, INTELIG, the scope of operation is the same as EMBRATEL's, being able to make long distance calls (inter and intra areas) but not in the local service. There is overlapping competition of EMBRATEL's mirror company only with the incumbent and mirror regional companies in the intra-area long distance service. Hence, there are four companies competing in the intra-region long distance service and only two in the other services (local and inter-area).

This is one striking difference between the BMTR and the UK model, where the duopolists were nation-wide operators. We summarize the differences among Brazil, the US and the UK below:

\footnotetext{
${ }^{6}$ This is an important and superior departure of the BMTR from the UK, since an auction is always a better mechanism to get more efficient operators compared with the "first claimant rule" that appointed Mercury as the second duopolist in the British experience. See Bulow and Klemperer (1996) for the theoretical comparison between auctions and negotiations.

${ }^{7}$ See Herrera (1998), Pires (1999) and Mattos (2001) for a more detailed explanation about the general rules of the BMTR.
} 


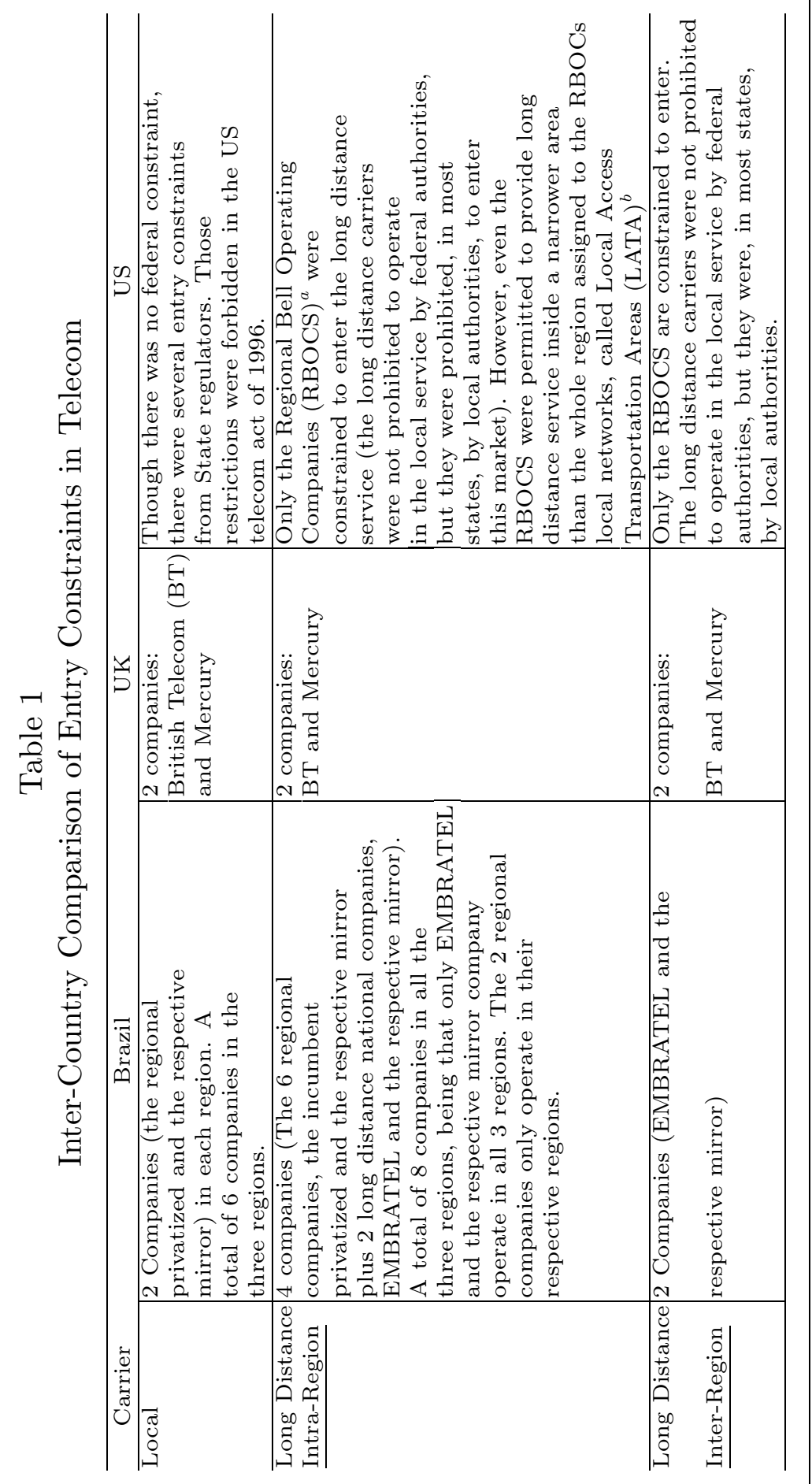

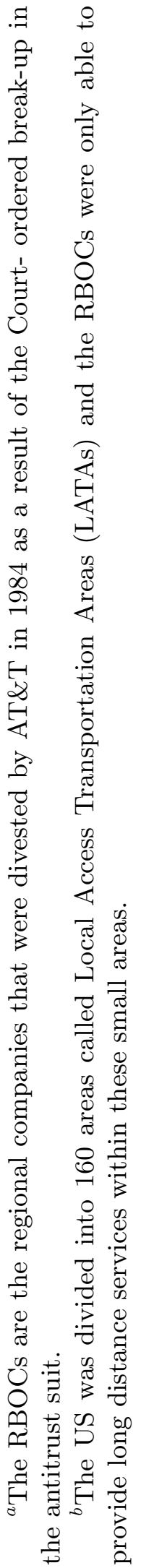


In the case of the wire telephone system, differently from the mobile one, the auctions for new grants occurred only after the privatization of the incumbent companies in TELEBRAS. ${ }^{8}$ According to the "General Guidelines to the Opening of the Telecommunications Sector in Brazil" (1997-GGTB), ${ }^{9}$ the main reason for this timing was the need to grant the incumbents enough time to prepare themselves for full-fledged competition, without constraints imposed on them, being state-owned companies.

Similarly to the British experience, the BMTR limited entry to two companies in a first moment, providing for a gradual liberalization afterwards until the achievement of a fully liberalised market. Figure 1 below shows the overall entry liberalization phasing out schedule in telecommunications in Brazil.

Figure 1

Schedule of the BMTR entry policy

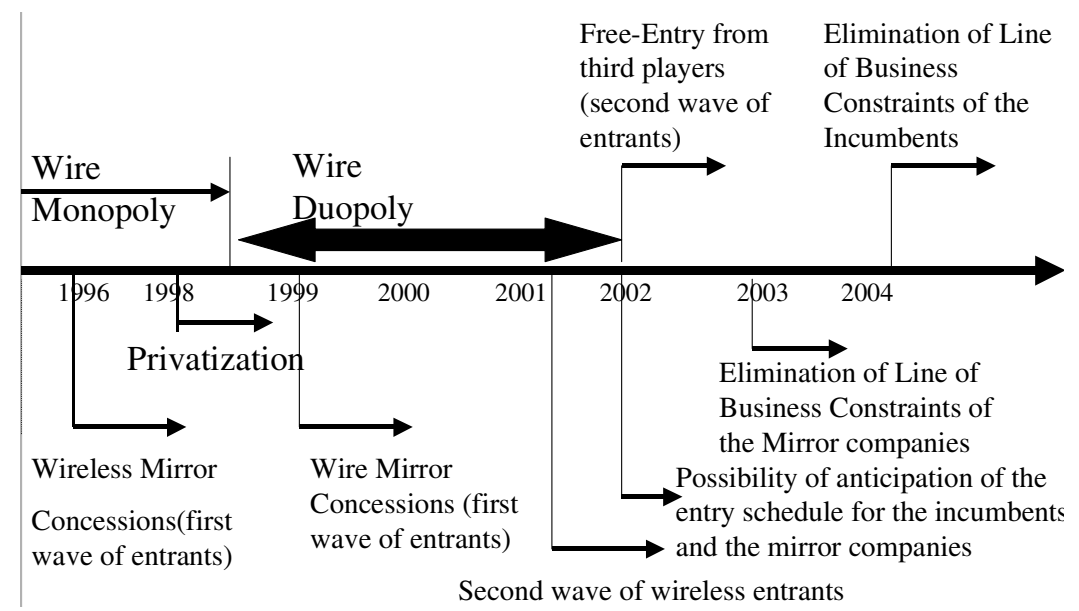

According to figure 1, there are four important deadlines in the BMTR entry schedule in the wire segment. First, there is a "second wave" of new entrants, entering without auctions or any other rationing rule after 2002. This second wave is completely free of entry constraints. After 2003, the first wave of entrants, owners

\footnotetext{
${ }^{8}$ In the case of the mobile companies, the auctions for the mirror-companies occurred before the privatization of the eight mobile companies owned by TELEBRAS, and it seems to have provided a good chance of growth to the entrants, as revealed by the current market-shares of the mobile mirror companies in some areas. See Novaes (2000) for an analysis of the first concessions of mobile services before privatization and its role in improving the experience of the regulator for selling TELEBRAS assets in the future.

${ }^{9}$ This document was used by the government as the general explanation introducing the bill of telecommunications reform to Congress after the Constitutional amendment that allowed for private ownership in this sector.
} 
of the mirror companies, got free of any constraints, too. Notice that this date can be anticipated to 2002, if they fulfill commitments of service supply established in their licenses. ${ }^{10}$ After 2004, there will be no entry or line of business constraints for all players with the liberalization of entry in other areas by the owners of the privatized companies. Also in this case, this schedule can be anticipated to 2002 with the anticipation of the universal targets fulfillment.

It is curious that the GGTB had argued so vigorously against entry constraints; nonetheless, the government adopted this policy afterwards. According to the GGTB, the risks of facilitated collusive behavior due to the duopoly policy would clearly offset some apparent advantages. ${ }^{11}$

\section{Revisiting the Main Theoretical Arguments in Favor of Limiting Entry}

There are simple explanations frequently offered by the regulatory authorities worldwide to justify policies of constraining entry. According to Armstrong (2000:2), "The argument usually given for temporary monopoly is that incumbents somehow require a "transitional" period to prepare for full-blown competition. The evidence is that a more effective way for inefficient incumbents to become competitive is actually to face competition. A more cynical explanation for such policies is that they are part of the "privatization contract", i.e. a kind of bribe paid to the incumbent (including both the employers and employees) to persuade it to support the privatization process".

In this section, we address arguments behind the imposition of entry limits, well grounded on the economic theory, assessing their relevance for telecommunications.

\footnotetext{
${ }^{10}$ These commitments were part of the auction bid for the license to be a mirror company.

${ }^{11}$ The collusive risk of the duopoly policy was stated in the following terms: "The investment in parallel infrastructure and price competition reduces the business value for both duopolists and, therefore, their most probable behavior will be a kind of tacit agreement that avoids or reduces these problems. The most likely result will be the consolidation of monopolies in well-defined areas, with some competition in the boundaries of those areas and for the most profitable users.... The non-limitation of the quantity of new operators, connected with the imposition of duties to the old operators, in terms of investment in new infrastructure, along the required time for the consolidation of an effectively competitive market, can eliminate most of the problems pointed out in the duopoly case........ The non-existence of a rigid duopolistic structure makes collusive agreements among operators toward the geographical division of the market harder, because there will always be a new company eager to invest in order to meet a non-fulfilled demand. Therefore, it's clear that the scenario where there were no limits to the quantity of operators seems to be better than those that impose such constraints; hence, scenarios with duopoly structures would not be recommended".
} 


\section{Natural Monopoly and Non-Sustainability}

The most important argument used by regulators in the past to justify regulatory entry restrictions in telecommunications is the conventional "natural monopoly" theory. A market is a "natural monopoly" if the cost function is subadditive. ${ }^{12}$ The rationale behind introducing entry constraints is to guarantee that, if it is more efficient to produce with a single monopolist supplier in the context of a sub-additive cost function, there will be no further entry to disturb an efficient result. The concern is the occurrence of a "non-sustainable natural monopoly" where, despite the efficiency of a single firm supply given by the natural monopoly condition, the market may not naturally achieve an actual monopoly. ${ }^{13,14}$ In that case, there could be profitable entry, "cream-skimming" the market in an inefficient manner. The same rationale is directly extended to the cases of a "natural duopoly" when the most efficient number of firms in the market is two, or even other positive integers.

This view can be challenged on the following grounds. First, it is not clear which segments of telecommunications remain natural monopolies, mainly in the long distance. ${ }^{15}$ Second, the risk of a non-sustainable natural monopoly (or duopoly and so on) is more decisive in the context of a contestable market like that described by Baumol et al. (1982), and this is not a suitable hypothesis for telecommunications.

Furthermore, a non-sustainable monopoly or duopoly depend on the existence of scale and/or scope economies followed by scale and/or scope diseconomies in the relevant range of operation. There is no systematic evidence, however, in favor of the scale economies hypothesis in the telecommunications sector and even less evidence showing diseconomies of scale in this sector. ${ }^{16}$ In that case, being

\footnotetext{
${ }^{12}$ According to Tirole $(1988: 19)$, the general multi-product mathematical definition of a strictly sub-additive cost function is $C\left(\sum_{i=1}^{n} q_{i}\right) \leq \sum_{i=1}^{n} C\left(q_{i}\right)$ for any n-tuple of outputs $q_{1}, \ldots \ldots . . q_{n}$.

${ }^{13}$ See Viscusi et al. (1995:357).

${ }^{14}$ Note that the idea behind sustainability is not only linked to natural monopoly but to any monopoly. According to Spulber (1989:138), "a sustainable monopoly price refers to a marketclearing price vector in such a way that the monopolist is able to break even and additional entry is unprofitable".

${ }^{15}$ The history of the intercity US telecommunications market provides an illustration of a progressive weakening of the natural monopoly argument, as can be seen in Viscusi et al. (1995:487).

${ }^{16}$ See the early evidence in the survey by Fuss (1983) and in the updating of Waverman (1989:83-95). This latter author concludes that "the weight of the evidence in all these studies is simply not strong enough, since changing the level of aggregation, the functional form, the constraints imposed, or the objective function dramatically alters the results. The message is simply that the data available are insufficient to enable researchers to discriminate between alternative
} 
sustainable, the natural monopoly will also be a de facto monopoly if the regulator lets the market work. Hence, the constraint becomes meaningless ${ }^{17}$ and, consequently, imposing entry constraints in telecommunications on the basis of the natural monopoly hypothesis does not seem reasonable. Vickers and Yarrow (1988) reinforce these critiques in the context of the UK duopoly policy, pointing at three weaknesses of the argument: it cannot be taken for granted that cost conditions are naturally monopolistic with today's technology; even if natural monopoly conditions do in fact exist and actual entry does not occur, it still has desirable incentive effects on the incumbents' behavior and; free entry undermines collusion among incumbents.

\section{Universal Service and Non-Sustainability}

Non-sustainability can also occur through the imposition of universal service duties in different areas that imply cross-subsidization. This is particularly important for Brazil since the geographic extent of the country and the profound regional and social differences explain the relatively more important role performed by the universal service target in Brazil than in other more developed countries. Furthermore, besides the need to avoid increased regional imbalances, there was the need to guarantee political support for the privatization program in the country. Given the relatively high political significance of the less developed regions, ${ }^{18}$ a perceived lack of federal government commitment to the universal service target could dampen the political support for privatization. As we will see now, the funding of universal service and the theory behind non-sustainability are strongly linked. Armstrong et al. (1994) state that the issue of non-sustainability is more

hypotheses.................. My view is that the sub-additive test for aggregate ATET data is so sensitive to data and to econometric technique that it cannot be relied upon for making policy". Waverman (1989:94) guesses that, given the huge size of AT\&T, scale and scope economies between 1947/77 were unlikely. Shin and Ying (1992) aimed to circumvent methodological problems from the earlier studies, concluding for the non-existence (at a regional level) of scale economies in telecommunications. More contemporaneously, see also the survey of Fuss and Waverman (2002). Interestingly, the same debate about the existence of scale and scope economies in the wire sector is occurring in the mobile sector. While McKenzie and Small (1997) found that scale economies exist in the US mobile segment only up to a small range of subscribers, Foreman and Beauvais (1999), criticising the small sample exercise performed by the former, found significant scale economies for the GTE mobile company.

${ }^{17}$ The main criticism by Armstrong et al. (1994:106) about the practical possibility of nonsustainability is that it requires the strong hypothesis behind the conventional "contestable markets" theory.

${ }^{18}$ See Serra (1995, chapter 3). 
likely to occur as a consequence of distortions brought about by the regulatory framework, such as requirements of free supply or constraints on pricing structure. Viscusi et al. (1995:484-486) provide a simple graphic example with two goods with regulated prices and a break-even constraint that results in cream-skimming and inefficient entry. The hypothesis that leads to this result is the existence of cross-subsidization where one tariff is fixed at a price above its stand-alone average cost $(\mathrm{AC})$ and average incremental costs (AIC) and the other is fixed below both. ${ }^{19}$

We reproduce the graphs of Viscusi et al. (1995:486) below in figure 2 and assume that the regulator defines the "universal service" target as a minimum quantity just like in the BMTR. For example, the regulator imposes the minimum quantity of local service (or in a given area) as " $Y$ ", given by $Q_{y 0}$ on the right hand graph in figure 2.

Figure 2

Cross subsidization and cream-skimming

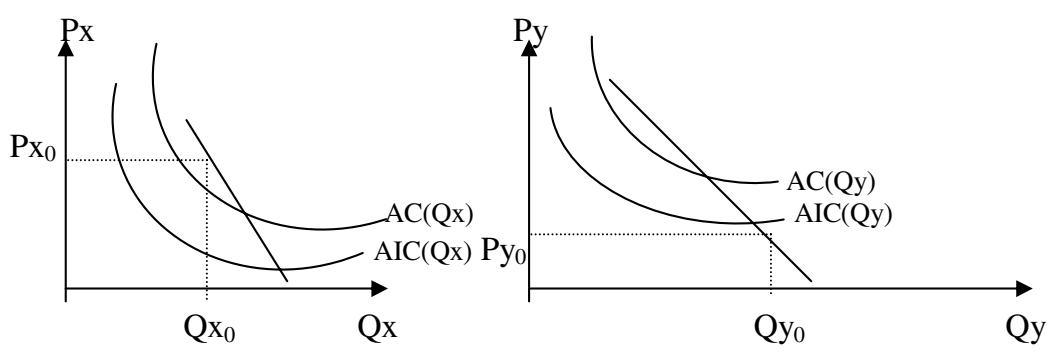

Clearly, universal service involves negative profits in market $Y$, given the price that the firm has to charge to generate that demand and given the stand-alone average cost $(\mathrm{AC})$ and the average incremental cost (AIC) curves of providing this service jointly with the long distance service $X$. Assuming that the firm must break-even to continue its operation, the regulator has to allow for positive profits in the long distance market $X$ that cover the damages in market $Y$. Assume that $P_{x o}$ and $Q_{x o}$ on the left hand side in figure 2 are such that:

$$
P x_{0} Q x_{0}+P y_{0} Q y_{0}-C\left(Q x_{0}, Q y_{0}\right)=0
$$

Note that the equilibrium point on the demand curve in market $X$ is above the respective incremental average cost curve $(\mathrm{AIC}(Q x))$ implying a positive profit in market $X$.

\footnotetext{
${ }^{19}$ The average incremental cost of $Q x$ is given by the formula $A I C(Q x)=\frac{C\left(Q_{x}, Q_{y}\right)-C\left(0, Q_{y}\right)}{Q_{x}}$.
} 
In this configuration, cream-skimming or the incentive for an entrant to enter the most profitable service $X$ (the cream), leaving the non-profitable one, $Y$, unattended (the milk), is very likely. An entrant can fix a price in $X, P_{x e}$, slightly lower than $P_{x o}$ but still superior to the stand-alone average cost of producing $\mathrm{X}$, $\operatorname{AC}\left(Q_{x}\right)$, stealing all the profitable market. In that case, the universal service in the local service (or area) $Y$ has to be funded by external sources, which is not a desirable result for the regulator. Therefore, the regulator has an incentive to block entry in $X$ to avoid cream-skimming and to make universal service a feasible task without providing external sources for its funding. Note that cream-skimming in this example comes from tariff regulation that implies a cross-subsidization scheme imposed by the government and not from the classical explanation based on the market forces indicated above.

On the other hand, even if one takes for granted that universal service targeting is crucial, the minimum quantities scheme described is not the best policy response. Indeed, as Armstrong (2000) stresses, the imposition of a barrier to entry is not the best way to handle this problem and alternatives like a "universal service fund" 20 and auctions for the subsidies are more interesting, which undermines the "nonsustainability through universal service" argument that favors entry constraints.

\section{Business Stealing Effect}

Another theoretical rationale for imposing institutional barriers to entry originates from the "business stealing effect". Several authors have shown how this effect occurs. Von Weizsaker (1980) built a model where scale economies brought on the possibility that the equilibrium number of companies could be excessive. Perry (1984) proposed a more general setting with scale economies and showed that, within a very large range of conjectural variation models, the "excess entry result" can appear. The most known contribution comes from Mankiw and Whinston (1986). They show that the negative marginal externality of additional entry on the incumbents more than offsets the gain of consumers from more competition. $^{21,22}$

\footnotetext{
${ }^{20}$ This kind of fund is being implemented in Brazil.

${ }^{21}$ While those papers study free market equilibrium, Harris (1981) and Suzumura and Kiyono (1987) examine the problem under price and entry regulation. See also Seade (1980) and Berry and Waldfogel (1999) for an empirical evaluation of those losses in the radiobroadcasting segment.

${ }^{22}$ There are several instances where the entrants do not take into account some negative externality over the incumbents and this can decrease welfare. Stiglitz (1981), for example, argues that this is the case of the relationship between competition and the conventional "excessive R\&D expenditures result" and when there are important learning-by-doing effects that increase with
} 
Armstrong et al. (1994:106-107) assesses the "business-stealing" problem in a non-formalized way, aiming at analysing its usefulness as a guideline for policy prescription in the case of the privatization of British Telecom in the UK. ${ }^{23}$ The authors (1994:108-109) ask if a corollary of this result would be that the imposition of constraints on the number of entrants would be better than full liberalization. The authors' answer is a big $\underline{\mathrm{NO}}$ since: more weight can be given to consumers in the welfare criterion; the benefit to the consumer implied by product differentiation may overturn the result; entry constraints may stimulate collusive behavior; asymmetric information tends to make free market preferable to a benign regulator; entry constraint eliminates the Darwinian property of competition that selects the most efficient firms; it is not plausible to assume, in telecommunications, that "entrants instantly became full-sized replicas of incumbents, with no need to build capital over time".

Furthermore, returning to the paper by Mankiw (1986:56), we have the result that the welfare loss due to free entry diminishes as the fixed costs required to enter decrease. In this regard, it is relevant to mention that in the technological history of this sector, the fixed costs requirements have been decreasing, including the advent of fibre-optics. Thus, we can also state that the eventual loss of welfare due to the "excess entry result" in telecommunications tends to be much lower than in the past.

\section{Under-Investment}

Armstrong and Vickers (1996) evaluate the trade-offs involved in allowing freeentry in telecommunications immediately compared to a phasing-in scheme that postpones full liberalization, in the transition economies of Central and Eastern Europe. The authors assume that the main concern about telecommunications and infrastructure in these countries relates to a tendency towards under-investment, given the lack of credibility of the regulatory institutions. The authors also stress the risk of wasteful duplication of facilities causing costly delay of investments in the case of a free-entry policy. Duplication would be particularly costly in transition economies because the low level of demand indicates that natural monopoly conditions are still prevalent. ${ }^{24}$ While the previous three arguments were discussed

the quantity per firm. See also Propositions 4, 5 and 7 of Reinganum (1989:857).

${ }^{23}$ According to the authors, "where scale economies are present, there is a trade-off - more competition is likely to improve allocative efficiency but at the expense of some productive efficiency".

${ }^{24}$ In this context, there is a "wait and see" behavior, given the existence of information 
theoretically, the relevance of the "under-investment" effect requires a discussion based on the relevance of these concerns for the Brazilian economy and the BMTR.

As we emphasized in the introduction, the Brazilian government implemented a regulatory framework that was more comprehensive, credible and transparent to private agents than other similar experiences. Most of the implementation of the BMTR happened between 1995 (the constitutional amendment) and 1998 (privatization of the wire companies), a period during which the credibility of the market reforms in Brazil was largely sustained by the successful stabilization of inflation through the Real Plan in 1994. Moreover, the same Finance Minister who was elected President, Fernando Henrique Cardoso, undertook the stabilization plan for 1995/1998. One of the great virtues of the Brazilian stabilization plan was that no contracts were broken and all market rules were kept intact in contrast with previous plans. In this regard, the credibility obtained with the stabilization plan favored the credibility of the pro-market reforms.

Even in periods of strong state intervention in the country, the presence of transnational companies in the Brazilian economy was substantive. Foreign business was already well rooted in Brazil. Hence, the BMTR did not suffer from the same historical credibility problems of the ex-communist countries. The speed of reforms in Brazil was not as important as in the former communist countries, where even the introduction of a market system could not be taken for granted.

The increased investment in the Brazilian telecommunication infrastructure was significant, but the gap between supply and demand was not as great as in the former communist countries. A more efficient telecommunications sector is more important in Brazil than an increase in investment "at any cost".

Given the general perception of the telecommunications market excellent prospects in Brazil, the "wait and see" hypothesis does not seem applicable to Brazil. The risk of expropriation in Brazil does not look greater than in developed countries. $^{25}$ The Brazilian population, territory and economy are big enough to suggest that the long distance service is not a natural monopoly in the country.

Therefore, the conditions of the Brazilian economy do not resemble the ones existent in the former communist countries. In any case, the arguments in favor of a phasing-in of the entry constraints in the former communist countries are not as strong as the arguments favoring immediate competition after (or even before)

\footnotetext{
externalities.

${ }^{25}$ In the UK, for instance, the price cap X values established for the power sector were reviewed in 1995, before the previously established date to do so. This was very criticized by economists, given its negative impact on the credibility of this price cap system and, thus, on the incentives for efficiency that it should provide. See Newbery (2000).
} 
privatization. ${ }^{26}$ The important issues to consider in the Brazilian case are more related to the developed countries' experience than to the former communist countries'. In the next section, we assess the trade-off between privatization revenues, scale economies and competition after privatization.

\section{A Theoretical Model for Understanding the Trade-offs among Competition, Scale Economies and privatization Revenues}

In every privatization program around the world, one of the most important targets has been the generation of public revenues through the sale of the companies. In countries with deep fiscal imbalances, or in a period of price stabilization like in Brazil and Argentina, the "public revenue" target becomes even more prominent.

The fundamentals of the Brazilian 1994 stabilization program could not be taken for granted by 1998 and the privatization policy performed an important macroeconomic role. When they reformed their telecommunications, the UK and US governments were not pressed by the same macroeconomic constraints as in Brazil. Nevertheless, the privatization revenues were relatively less important in Brazil than they were in other countries that proceeded with the privatization program as a major part of the stabilization plan or even with the overall reform program as in Argentina's case. ${ }^{27}$ In those cases, the relative weight of the macroeconomic purpose in the privatization program was even more prominent.

In addition, it is important to note that, in Brazil, the amount of revenues raised through the privatization program was taken as one of the main indicators of the success of the policy. The higher the expected market power of the company after privatization, the higher its expected future profits, the higher the expected bids in the privatization auction and, likewise, the higher the public revenues to be raised. The revenues obtained in the program are an objective and immediate result to be shown to the public.

Some formalization generates further insights for the intuitive rationale behind

\footnotetext{
${ }^{26}$ Note the Armstrong and Vickers' conclusion (1996:313) in favor of a policy of short-run entry constraints in the wire segment for the former communist countries is much less than "enthusiastic": "These considerations have led us to the conclusion that a reasonable case can be made - we put it no stronger - for phased rather than immediate liberalization in basic fixed-link telephony, provided that there is ex-ante competition for any time-limited monopoly concession, that its duration is short, that explicit investment requirements are agreed on in return for the concession, and that there are effective safeguards against monopolistic abuse in interim".

${ }^{27}$ See Abdala and Hill (1996).
} 
the trade-offs involved in a privatization program. We build a model that shows the trade-offs among competition, privatization revenues and scale economies, since all infrastructure sectors such as telecommunications tend to present non-negligible fixed costs.

We take as given the format of the auction as a first-sealed bid auction, as was partially the case of the BMTR, and follow the basic framework developed by Klemperer (2000). The author assumes $n$ bidders with independent private values. Each bidder $i$ has values $V_{i}$ over the object (the company) to be sold, independently drawn from the same continuous distribution function $G(V)$ on the interval $[\bar{V}, \underline{V})$ with density $g(V)$. Bidders do not know each other's types, but only the distribution $G($.$) from which those types are drawn. This distribution function is$ supposedly uniform. The seller (government) also knows this distribution. The minimum price that the seller defines for the sale of the company is $\underline{V}$. Klemperer (2000) shows that the expected revenue, ER, of the seller is

$$
E R=\underline{V}+\frac{n-1}{n+1}(\bar{V}-\underline{V})
$$

Next, we pass to an analysis of the market conditions after privatization and its expected impact on the privatization revenues and the general maximization problem of the government. We pick a Cournot oligopoly model with $m$ players provided by Tirole (1988:220), introducing a fixed cost $F_{i}$ specific to each player. Suppose the following linear demand function and the $m$ symmetric individual cost curves:

$$
\begin{gathered}
P(Q)=1-Q \\
C_{i}\left(q_{i}\right)=c q_{i}+F_{i} \quad \text { for } i=1 \ldots m
\end{gathered}
$$

with $c<1$.

$$
Q=\sum_{i=1}^{m} q_{i}
$$

The equilibrium profit, quantity and price values are derived from the firstorder condition. 


$$
\begin{aligned}
\prod_{i} & =\frac{(1-c)^{2}}{(m+1)^{2}}-F_{i} \\
q_{i} & =\frac{(1-c)}{(m+1)}
\end{aligned}
$$

The total flow of profits equals the type $V_{i}$ of the firm. As the first part of the profit function is constant across all firms for a given number of players $m$, the difference will be given by the fixed cost $F_{i}$. This is supposed to be the required fixed cost for each player type to supply any quantity at the constant marginal cost $c$ in each period. The higher $F_{i}$, the closer $V_{i}$ will be to the least efficient type $\underline{V}$. The maximum and minimum values of the fixed cost found in the distribution function $G(V)$ are given, without loss of generality, by $F_{h}$ ( $F$ high) and 0 . Assuming that the number of players will remain constant, we find:

$$
V_{i}=\frac{(1-c)^{2}}{(m+1)^{2}}-F_{i}
$$

Applying (6) in (7) we have that $\underline{V}$ and $\bar{V}$ will be given by

$$
\begin{gathered}
\underline{V}=\frac{(1-c)^{2}}{(m+1)^{2}}-F_{h} \\
\bar{V}=\frac{(1-c)^{2}}{(m+1)^{2}}
\end{gathered}
$$

Replacing (8) and (9) in (2), we reach the expected revenue of the government in the privatization auction:

$$
\begin{aligned}
& E R=\frac{(1-c)^{2}}{(m+1)^{2}}-F_{h}+\frac{(n-1)}{(n+1)}\left[\frac{(1-c)^{2}}{(m+1)^{2}}-\frac{(1-c)^{2}}{(m+1)^{2}}+F_{h}\right] \\
& E R=\frac{(1-c)^{2}}{(m+1)^{2}}-F_{h}+\frac{(n-1)}{(n+1)} F_{h}
\end{aligned}
$$

Note that the expected revenue always decreases with the number of firms:

$$
\frac{\partial E R}{\partial m}=\frac{-2(1-c)^{2}}{(m+1)^{3}}<0
$$

When the government only cares about privatization revenues, it always minimizes the number of players to be allowed in the market as much as possible. The 
expected revenue of the privatization auction is always decreasing in the number of players allowed to enter, and then it makes sense to constrain the number of players ex ante to achieve a higher amount of privatization revenues. The intuition is very straight: The greater the ex-post number of players in the market, the lower the market power rents to be appropriated and thus the lower the value of the company for any player, reducing expected revenue.

Now, we incorporate the standard measure of social welfare $W(Q)$. Social welfare will be given by the following expression, approximating the total surplus by the integral:

$$
E(W(Q))=\int_{0}^{Q} P(x) d x-c Q-\sum_{i=1}^{m} E\left(F_{i}\right)
$$

Solving the integral, we obtain

$$
\begin{aligned}
E(W(Q)) & =\frac{-(1-Q)^{2}}{2}+\frac{1}{2}-c Q-\sum_{i=1}^{m} E\left(F_{i}\right)=\frac{2 Q-Q^{2}}{2} \\
& -c Q-\sum_{i=1}^{m} E\left(F_{i}\right)=\frac{Q(2-Q-2 c)}{2}-\sum_{i=1}^{m} E\left(F_{i}\right)
\end{aligned}
$$

Replacing the equilibrium quantity from (6) in (13), we obtain:

$$
\begin{aligned}
E(W(c, m)) & =m \frac{(1-c)}{m+1} * \frac{\left(2-\frac{(1-c) m}{m+1}-2 c\right)}{2}-\sum_{i=1}^{m} E\left(F_{i}\right) \\
& =\frac{m(m+2)(1-c)^{2}}{2(m+1)^{2}}-\sum_{i=1}^{m} E\left(F_{i}\right)
\end{aligned}
$$

This is the total surplus as a function of the marginal cost $c$, the number of firms $m$ operating in the market in a Cournot equilibrium and the sum of the expected fixed costs of all these $m$ firms. Given that $G$. is a uniform distribution, so is the distribution of the fixed costs that we define as $H($.$) . Furthermore, we$ suppose that entry occurs by order of efficiency and all players that aim to enter are among the $n$ bidders of the privatization auction. The expected $m$ players to enter are always the most efficient ones. The expectation of the fixed cost of the 
$i^{\text {th }}$ player to enter is ${ }^{28}$

$$
E F_{(i)}=\frac{i F_{h}}{n+1}
$$

and so,

$$
E(W(c, m))=\frac{m(m+2)(1-c)^{2}}{2(m+1)^{2}}-\sum_{i=1}^{m} \frac{i F_{h}}{n+1}
$$

The government weights total surplus from (14) by $1-\alpha$ and privatization revenues from (10) by $\alpha$ in its (assumed utility separable) objective function:

$$
G=\alpha E R+(1-\alpha) E W
$$

Furthermore, it does not make sense to have $m<1$. So, we add the constraint that $m \geq 1$,

$$
G=\alpha \frac{(1-c)^{2}}{(m+1)^{2}}-F_{h}+\frac{(n-1)}{(n+1)} F_{h}+(1-\alpha) \frac{m(m+2)(1-c)^{2}}{2(m+1)^{2}}-\sum_{i=1}^{m} \frac{i F_{h}}{n+1}
$$

We want to obtain the value of $m$ for which $G$ is maximum, considering the constraint that $m \geq 1$. As

$$
\frac{\partial G}{\partial m}=\frac{(1-3 \alpha)(1-c)^{2}}{(m+1)^{3}}-(1-\alpha) \frac{(2 m+1) F_{h}}{2(n+1)}
$$

We have that if $\alpha>1 / 3, \partial G / \partial m<0$ everywhere and thus the constraint binds $(m *=1)$. In this case, privatization revenues are important enough so that the objective function of the government always decreases with the number of players in the market. The lower $\alpha$, the weight of privatization revenues reduces, pushing the optimal number of firms $m^{*}$ upwards. ${ }^{29}$

The lower $F_{h}$, there is less expected fixed cost when new players enter the market, which makes competition relatively more desirable. Finally, the greater

\footnotetext{
${ }^{28}$ For any random variable, $X$, uniform in the interval $[a, b]$, with density function $f_{X}$ and distribution function $F_{X}$, the density of the statistics of order $k\left(Y_{k}\right)$ in a sample of $n$ values will be given by $f_{k}(x)=0$ for $x \notin[a, b]$ and $\left.f_{k}(y)=\frac{n !}{(k-1) !(n-k) !}\left[F_{x}(y)\right]\right]^{k-1}\left[1-F_{x}(y)\right]^{n-k} f_{X}(y)$. As $E Y_{k}=\int_{a}^{b} y f_{k}(y) d y$ and integrating by parts, we get the formula.

${ }^{29}$ Of course, depending on the functional form of the government's objective, the range of $\alpha$ for which $\partial G / \partial m<0$, will vary.
} 
the value of $c$ for $\alpha<1 / 3$, the lower the optimal number of firms. This occurs since, with a higher $c$, there will be less variable profit available to cover the fixed costs. We comment below on the case where $\alpha>1 / 3$.

An interesting aspect of (17) is that if it is negative for any $m=m_{j}$, it will also be negative for $m=m_{j}+1, m_{j}+2 \ldots \ldots \infty$. Note also that the introduction of privatization revenues in the problem just makes the optimal number of firms lower than otherwise. There would still be a finite optimal number of companies without it, given that the regulator also cares about minimizing fixed costs.

But nothing guarantees that the expected feasible number of firms in the market, $m_{f}$, is higher than the optimal $m^{*}$ from (17), which would make the entry constraint a relevant one. Formally, we define $m_{f}$ as the maximum integer value of $m$ such that

$$
\begin{gathered}
\frac{(1-c)^{2}}{\left(m_{f}+1\right)^{2}} \geq \frac{\left(2 m_{f}+1\right) F_{h}}{2(n+1)} \\
\frac{(1-c)^{2}}{\left(m_{f}+1\right)^{2}}-\frac{\left(2 m_{f}+1\right) F_{h}}{2(n+1)} \geq 0
\end{gathered}
$$

$m_{f}$ is the expected maximal number of firms that will voluntarily enter in a Cournot equilibrium. The effective number of firms $m_{e}$ in the market, with entry regulation ruled by (17), will be

$$
m_{e}=\operatorname{Min}\left(m_{f}, m *\right)
$$

If $m_{e}=m_{f}$, the institutional constraint imposed by the regulator is meaningless since the market itself will lead the number of firms as close as possible to the optimal. On the other hand, if $m_{e}=m^{*}$, the imposition of the constraint is binding and thus required to achieve the objective function of the regulator.

It is important to compare the influence of the exogenous variables of the model in $m_{f}$ and $m^{*}$. The greater $F_{h}$, the lower will $m^{*}$ and $m_{f}$ be. It is straightforward since larger fixed costs increase the social cost of entry (reducing $m^{*}$ ) and also the net profit of the competitors, reducing the stimulus for entry. Similarly, the larger the number of potential entrants $\mathrm{n}$, the larger the values of $m^{*}$ and $m_{f}$, since the expected fixed cost of the entrants also decreases.

An increase on $c$ always reduces $m_{f}$. On the other hand, $c$ brings ambiguous effects over $m^{*}$. An increase on $c$ impacts the derivative of the regulator's objective function in respect to the social surplus and to the expected privatization revenues of the government. The net effect depends crucially on $\alpha$. The higher this parameter, it becomes more likely that the second effect will be stronger and 
then $m^{*}$ will decrease. $\alpha$ also impacts $m^{*}$ directly (and not only indirectly through $c)$.

The comparison of (17) to (18) shows that if $\alpha>1 / 3$, the regulatory entry constraint will just be redundant when $m_{f}=1$. If $m_{f}>1$, the entry constraint binds. When $\alpha<1 / 3$, we can address the redundancy of the constraint by assessing the difference between (17) and (18) at $m_{f}$ :

$$
\frac{(1-c)^{2}\left[(1-3 \alpha)-\left(m_{f}+1\right)\right]}{\left(m_{f}+1\right)^{5}}+\frac{\alpha\left(2 m_{f}+1\right) F_{h}}{2(n+1)}
$$

If this difference is positive, $m^{*} \geq m f$ and the imposition of the constraint is redundant, since the market itself will define a ceiling in the number of entrants lower or equal to the optimal number of players for the regulator. If this difference is negative and large enough, ${ }^{30}$ the entry constraint starts to bind. The larger $F_{h}$, the more likely the entry constraint will not be active, since the firms care more about its impact on profits than the regulator cares about its impact on social welfare (according to (17), the regulator discounts $F_{h}$ by $(1-\alpha)$. Variations on $\alpha$ bring ambiguous results on (20) and the magnitudes of $c$ and $F_{h}$ define whether the expression is positive or negative. If

$$
\frac{3(1-c)^{2}}{\left(m_{f}+1\right)^{5}}>\frac{\left(2 m_{f}+1\right) F_{h}}{2(n+1)}
$$

an increase on $\alpha$ tends to make the entry constraint more relevant, following the basic intuition that this constraint matters more when privatization revenues are relatively more relevant for the objective function of the regulator. The problem is that this is not the single effect of $\alpha$. There is also an indirect effect of $\alpha$ through $F_{h}$, reducing the impact of this variable in (17), and making the impact of the fixed costs coming from the welfare function relatively less important. That is why the effect of $\alpha$ on the redundancy of the entry constraint is ambiguous. When $c$ is lower and $n$ is larger, positive variations of $\alpha$ tend to make the entry constraint more important since this increases the expected privatization revenues.

This model shows the intuition that the greater the concern of the regulator towards privatization revenues, the optimal number of players for the regulator is reduced. In this particular model, when the preference of the regulator is such that it valuates privatization revenues enough, in the sense that $\alpha \geq 1 / 3$, it is interested in a monopoly ex-post. It does not mean that increases (or decreases) on $\alpha$ always make the regulator relatively more interested in reducing (increasing)

\footnotetext{
${ }^{30}$ Considering that $m$ is an integer, there is a range where this difference is negative, but $m^{*}$ still equals $m_{f}$.
} 
the number of players ex-post. It depends on the relative magnitudes of $F_{h}$ and $c$ as addressed above. Furthermore, even if $\alpha \geq 1 / 3$, it does not mean that the constraint is not redundant. This occurs since $m_{f}$ given in (17) can be equal to 1 , making the imposition of an external constraint completely redundant in the model. Market equilibrium will naturally result in a monopoly.

\section{Lessons from the International Experience and Conclusions}

In the British experience, the great part of the duopoly policy ended at the beginning of the 90's. However, the duopoly policy remained in international calls to sustain the bargaining power of the UK companies relative to their foreign counterparts (most of them local monopolies) with whom they had to negotiate interconnection payments. The duopoly policy for the international operation was ended in June 1996 and, according to Armstrong (1998:69), nearly 50 license applications were submitted, which is a measure of the "repressed supply" at the time of market liberalization. ${ }^{31}$

According to Vickers and Yarrow (1991:239), the duopoly policy in the UK was usually justified on grounds of a version of the "infant industry" argument where the already operating Mercury should be protected while it was establishing itself in the market. There is an important logical problem with this argument. Armstrong (2000:4) points out that, if the second entrant makes the first entrant unprofitable, it is likely that the former may be more efficient and thus more preferable to be in the market than the latter. The authors also stress that the main protection that the UK government should have provided to Mercury would be against the anticompetitive practices of the BT, mainly in terms of the interconnection rules. Furthermore, the authors emphasize that a more efficient aid should be targeted directly to the entrant. If aid is not focused, as in the imposition of entry constraints, it is possible that more benefit will accrue to BT than to Mercury given the relative sizes of the two firms, disguising the objective of the policy.

Finally, Armstrong et al. (1994) conclude that the duopoly policy, even on a temporary basis, was shown not to be a good idea in the UK, since it became harder to overcome BT's first mover advantage: "In important respects, however, it was a decade of lost opportunities. The deliberate restrictions on competition contained in the duopoly policy, together with insufficient attention paid to overcoming BT's incumbency advantages, acted to preserve the essentially monopolistic character

\footnotetext{
${ }^{31}$ The duopoly policy in the UK lasted for 6 years (1984/1990) after privatization, against 3 years and a half in Brazil (1998/2001).
} 
of the old system in the core area of network operation. Neither did the duopoly policy enhance the prospects for competition in the longer term".

Newbery (2000:330) considers that even the argument of privatization revenues should not be taken so far, since the negotiations in the World Trade Organization (WTO) are pointing for the removal of entry constraints which would affect the prospects of future monopoly profits of the company buyers and that; the funds generated by a small increase in the value added tax VAT would be more efficient. The author attributes the choice of the UK government for a duopoly policy to the lack of parliamentary consensus about privatization, requiring that it be privatized quickly.

The empirical results of the policy of restricting entry in the UK and US point in the same direction. In the UK, Newbery (2000:323-324) shows that private ownership did not impact the sector's productivity in the six years after privatization, taking the experiences of other countries as parameters. After lifting entry constraints, productivity growth accelerated, suggesting that "it is competition that leads to an acceleration of productivity growth, not privatization". In the US, the empirical evidence studied by Mathios and Rogers (1989) shows that, in states where entry was restricted, average prices increased much more than in the states where there was a free-entry policy.

This suggests that a free-entry policy generates dynamic efficiencies that cannot be disregarded as in the case of the model developed above. In balance, these efficiencies may even outweigh the static efficiency loss due to wasteful duplication of facilities. In this regard, we firmly believe that the most relevant variable considered by the Brazilian regulators in following the same duopoly policy from the UK was, indeed, privatization revenues. The costs for long-run competition and efficiency are still to be seen.

\section{References}

Abdala, M. A. \& Hill, A. (1996). Argentina: The sequencing of privatisation and regulation. In Levy, B. \& Spiller, P., editor, Regulation, Institutions and Commitment: Comparative Studies of Telecommunications, pages 202-249. Cambridge University Press.

Armstrong, M. (1998). Telecommunications. In Helm, D. \& Jenkinson, T., editor, Competition in Regulated Industries. Oxford University Press.

Armstrong, M. (2000). Regulation and inefficient entry. University of Oxford. Mimeo. 
Armstrong, M., Cowan, S., \& Vickers, J. (1994). Regulatory Reform: Economic Analysis and British Experience. The MIT Press.

Armstrong, M. \& Vickers, J. (1996). Regulatory reform in telecommunications in Central and Eastern Europe. Economics of Transition, 4(2):295-318.

Baumol, W., Panzar, J., \& Willig, R. (1982). Contestable Markets and the Theory of Industry Structure. Harcourt Brace Jovanovich Publishers.

Baumol, W. \& Sidak, G. (1994). Toward competition in local telephony. AEI Studies in Telecommunications Deregulation. The MIT Press and the American Enterprise Institute for Public Policy Research.

Berry, S. T. \& Waldfogel, J. (1999). Free entry and social inefficiency in radio broadcasting. Rand Journal of Economics, 30(3):397-420.

Brazilian Government (2000). Diretrizes para a abertura das telecomunicações no Brasil. http://www.anatel.gov.br/biblioteca/index.htm.

Bulow, J. \& Klemperer, P. (1996). Auctions versus negotiations. American Economic Review, 86(1):180-194.

Cave, M. \& Williansom, P. (1996). Entry, competition and regulation in UK telecommunications. Oxford Review of Economic Policy, 12(4):100-120.

Cramton, P. (2002). Spectrum auctions. In Cave, M. \& Majumdar, S. \& Vogelsang, I., editors, Handbook of Telecommunications Economics, pages 606-640.

Foreman, R. D. \& Beauvais, E. (1999). Scale economies in cellular telephony: Size matters. Journal of Regulatory Economics, 16:297-306.

Fuss, M. \& Waverman, L. (2002). Econometric cost functions. In Cave, M. \& Majumdar, S. \& Vogelsang, I., editors, Handbook of Telecommunications Economics, chapter 5, pages 144-179. Elsevier.

Fuss, M. A. (1983). A survey of recent results in the analysis of production conditions in telecommunications. In Courville, L. \& Fontenay, A. \& Dobell, R., editors, Economic Y Analysis of Telecommunications: Theory and Applications. North Holland.

Harris, R. (1981). Price and entry regulations with large fixed costs. Quarterly Journal of Economics, pages 643-655. 
Herrera, A. (1998). Reforma del sector de telecomunicaciones en Brasil: Asimetría regulatoria, competencia y universalización de los servicios. Mimeo.

Kiss, F., Karabadjian, S., \& Lefebvre, B. J. (1983). Economies of scale and scope in bell Canada.

Klemperer, P. (2000). The Economic Theory of Auctions. Edgard Elgar Publisher.

Mankiw, N. G. \& Whinston, M. D. (1986). Free entry and social inefficiency. Rand Journal of Economics, 17(1):48-57.

Mathios, A. D. \& Rogers, R. P. (1989). The impact of alternative forms of state regulation of AT\&T on direct-dial, long-distance telephone rates. Rand Journal of Economics, 20(3):437-453.

Mattos, C. C. A. (2001). O modelo brasileiro de reforma das telecomunicações: Uma abordagem teórica. Tese de Doutorado. UNB/DF.

McKenzie, D. J. \& Small, J. P. (1997). Econometric cost structure estimates for cellular telephony in the United States. Journal of Regulatory Economics, 12:147-157.

Nelson, R. \& Winter, S. (1982). An Evolutionary Theory of Economic Change. The Belknap Press of Harvard University Press.

Newbery, D. (2000). Privatisation, Restructuring and Regulation of Network Industries. The Walras-Parecto Lectures. The MIT Press.

Novaes, A. (2000). Privatização do setor de telecomunicações no Brasil. In $A$ Privatização No Brasil: O Caso Dos Serviços de Utilidade Pública. BNDES.

Perry, M. (1984). Scale economies, imperfect competition and public policy. The Journal of Industrial Economics, XXXII(3):313-333.

Phlips, L. (1995). Competition Policy: A Game Theoretic Perspective. Cambridge University Press.

Pires, J. C. L. (1999). A reestruturação do setor de telecomunicações no Brasil. Revista do BNDES, N. 11.

Reinganum, J. (1989). The timing of innovation: Research, development and diffusion. In Schmalensee, R. \& Willig, R., editor, Handbook of Industrial Organization, pages 848-908. 
Scherer, F. M. \& Ross, D. (1982). Industrial Market Structure and Economic Performance. Houghton Mifflin Company, Boston.

Seade, J. (1980). On the effects of entry. Econometrica, 48(2):479-489.

Selten, R. (1973). A simple model of imperfect competition where four are few and six are many. International Journal of Game Theory, 2. Reprinted in Selten, R. Models of Strategic Rationality, Kluwer Academic Publishers, 1988.

Serra, J. (1995). Reforma Política No Brasil. Editora Siciliano, 3 edition.

Shin, R. \& Ying, J. (1992). Unnatural monopolies in local telephony. Rand Journal of Economics, 23(2):171-183.

Spulber, D. (1989). Regulation and Markets. The MIT Press.

Stiglitz, J. (1981). Potential competition may reduce welfare. AEA Papers and Proceedings, 71(2):184-189.

Sutton, J. (1998). Technology and Market Structure: Theory and History. The MIT Press.

Suzumura, K. \& Kiyono, K. (1987). Entry barriers and economic welfare. Review of Economic Studies, LIV:157-167.

Tirole, J. (1988). The Theory of Industrial Organization. The MIT Press.

Vickers, J. \& Yarrow, G. (1988). Privatization: An Economic Analysis. MIT Press, MA.

Viscusi, W., Vernon, J., \& Harrington, J. (1995.). Economics of Regulation and Antitrust. The MIT Press.

Von Weizsaker, C. C. (1980). A welfare analysis of barriers to entry. Bell Journal of Economics, pages 399-420.

Waverman, L. (1989). US interexchange competition. In Crandall, R. W. \& Flamm, K., editor, Changing the Rules: Technological Change, International Competition and Regulation in Communication. The Brookings Institution, Washington, D.C. 